\title{
CO-OPTING THE RIVAL \\ CA(N)NON: THE TURKISH \\ EPISODE OF HIKAYAT HANG \\ TUAH
}

\author{
Vladimir Braginsky \\ vb1@soas.ac.uk
}

School of Oriental and African Studies (SOAS)

University of London

\begin{abstract}
Among specimens of traditional Malay literary polemics, or rather, "wars of books", we find an interesting group of texts of the mid or late seventeenth century, which narrate how an Acehnese embassy was dispatched to Ottoman Turkey to obtain "large cannons". Remarkably, alongside literary pieces composed in Aceh, this group also includes the Turkish episode of Hikayat Hang Tuah (HHT), the epic created in Johor which describes the epoch of the Malaccan sultanate. However, HHT is a double-layered work in which Malacca not infrequently stands for Johor, whose relations with Aceh were more often than not hostile. HHT's author covertly polemicizes against Acehnese literary works, striving to prove that Malacca (read Johor) allegedly established diplomatic relations with the Ottomans earlier than Aceh. HHT also attempts to show that its mission to Istanbul was much more successful than Aceh's and that it completed the recognition of Malacca/Johor across the entire political space from China to Turkey. Yet, the political and literary agendas of HHT's author differ radically. In the former, the forces of repulsion hold sway, which leads HHT to depict the triumph of Johor in its rivalry with Aceh. In the latter, on the contrary, the forces of attraction dominate. For this reason the Turkish episode in HHT borrows the plot of Acehnese works, constructs its portrayals of Istanbul from a mosaic of Acehnese sources, and resorts to the grand Acehnese literary style of the "gold-and-jewel" variety.
\end{abstract}


Keywords: traditional Malay literature, Hikayat Hang Tuah, Malacca, Johor, Aceh, Turkey, Istanbul, the Ottomans, Acehnese embassy, political agenda, palimpsest, war of books, gold-and-jewel style

\section{THE ACEHNESE EMBASSY TO THE OTTOMANS IN HISTORY, ACEHNESE LITERARY WORKS, AND HIKAYAT HANG TUAH}

Among the fairly numerous pieces of traditional Malay literature which tell of various things Turkish-real, imaginary and altogether mythical-or unfold their plots against Turkish backdrops, there is an interesting group of works united by a historical event that in its time marked the first face-to-face encounter of the Malay world with Ottoman Turkey. This group consists of a few Acehnese texts dating from the mid or late seventeenth century. ${ }^{1}$ These are a passage from Bustan al-Salatin (Garden of Sultans; henceforth Bustan) by Nuruddin al-Raniri, two versions of the legend of the cannon named Secupak Lada (A Quart of Pepper) and a section from Hikayat Aceh. The same group also includes the Turkish episode of the Johorese text Hikayat Hang Tuah (henceforth HHT)-the major object of this study-roughly dateable to the same era. The event that constitutes the common theme of these texts is the embassy (in fact, a series of embassies) sent by the sultan of Aceh, Alauddin Riayat Syah al-Kahar (who reigned circa 1539-1571), to Istanbul in search of military assistance against the Portuguese.

A historical background of these texts can be summarized as follows: ${ }^{2}$ Having subdued his local rivals (Aru and Johor), Alauddin decided to open hostilities against the Portuguese with whom, despite occasional clashes, Aceh had until then maintained largely peaceful relations. Between 1547 and 1571 he dispatched five missions to the court of Suleiman the Magnificent (15201566) and Selim II (1566-1574) reciprocated by two Turkish embassies to Aceh, all with a plea for military help. The exchanges of embassies in 15623-1564-5 and 1566-8-1568 are particularly important for the understanding of the texts in question. In the case of the former, the Ottoman reaction to the ambassadors' requests for "large cannons", cannon-founders and artillerists was so chilly that the ambassadors seem to have not even gained an audience with the sultan (Casale, 2005:58). ${ }^{3}$ The reason for this cool reception was mainly a concern of the Sublime Porte that complying with Alauddin's plea may have harmed their trade negotiations with the Portuguese, which the grand-vizier Semiz Ali was conducting precisely at that time. Under the pretext that safe routes for the transportation of cannons should be thoroughly 
investigated first, the Porte virtually refused the Acehnese request. Yet, as a kind of concession, the Turkish agreed to send ten artillery experts to Aceh and dispatched the agent Lutfi as the Ottoman envoy to Alauddin's court. Lutfi's commission was indeed to ascertain safe routes for the transportation of cannons, but also to investigate the seriousness of the Acehnese intentions to fight the Portuguese.

After two years in Aceh, Lutfi arrived in Istanbul on a return mission, bringing a royal letter in which, having asked once again for military assistance, Alauddin suggested that Aceh should be granted the status of a vassal-state under the Ottoman suzerainty. The ambassadors had to wait for two years for the Porte's reply. Sultan Suleiman was engaged in military operations in Hungary, and died soon after his return to Istanbul. Subsequently, the Porte was busy with Selim II's enthronement and pressing matters related to the change of monarch. Luckily for the Acehnese, Sokollu Mehmet replaced Semiz Ali as grand-vizier. Striving to secure Ottoman command of the sea, Sokollu Mehmet initiated a policy of ousting the Portuguese from the Indian Ocean with the help of the rulers of Muslim maritime states of the region (Gujarat, Bijapur, Calicut and the Maldives). The rendering of military help to Aceh perfectly conformed to his policy and this time the help was impressive indeed. Aceh received a fleet of fifteen galleys (later four more galleys would join the mission) and two transport vessels. All these ships, fully armed and manned, were to deliver cannons and experts (canonneers, shipwrights and specialists in the storming of castles) to Aceh.

However, fate still did not favour the Acehnese. Soon after the departure of the fleet a powerful uprising broke out in Yemen and the fleet had to be recalled to put it down. Only two ships (probably belonging to private traders) with cannons, ammunition and a number of gunsmiths on board reached Aceh. This proved to be insufficient for Alauddin to capture Portuguese Malacca and his assault on the city in 1568 failed. In 1569 and 1571 Alauddin sent two more missions to Istanbul, each time receiving the promise that the fleet would arrive as soon as the wars first in Yemen and later in Cyprus and Tunisia were completed. Yet the fleet never materialized. As Sokollu Mehmet Pasha's policy in the Indian Ocean did not bear its expected fruit, and Selim II's successor Murad III (1574-1595) showed no interest in further naval operations, the whole affair came to nothing. The Acehnese failed to seize Malacca, both in the era of Alauddin and later in the reign of the Sultan Iskandar Muda (1607-1636). More than half a dozen Acehnese attacks against this stronghold of the Portuguese in the Malay world failed, 
and the city fell only in 1641 to a coalition of the Dutch and the Sultanate of Johor, Aceh's rival, in which Aceh had short-sightedly refused to participate (Sher Banu, 2010:303-22).

While passing from the historical events thus described to their reflection in the above-mentioned Acehnese texts, two salient features are particularly striking. On the one hand, although the motif of military assistance occurs in all these texts, any mention of the Portuguese as the threat against which the assistance was sought is significantly absent. Even the relatively reliable al-Raniri evasively refers to the Portuguese only as the "infidels of Malacca" (Jelani, 2004:338). Both versions of the legend of Secupak Lada ignore the Portuguese altogether. Hikayat Aceh, a chronicle that covers the history of Aceh until Iskandar Muda's reign (1607-1636), a period in which the Portuguese featured prominently, mentions them only twice. The first mention is in a story of mock-battles in which little Iskandar Muda and his friends played the Acehnese against Iskandar Muda's brother and his brother's teammates, who represented a captain of the Portuguese and the Portuguese forces respectively. The second mention occurs in a story of two pseudo-Portuguese, Dong Dawis and Dong Tumis (in fact, the British Davis and Tomkins), who competed with young Iskandar Muda in horse racing and unsurprisingly lost (Iskandar, 2001:61-66, 67-72). Thus, the chronicle (at least in its extant manuscripts) tolerates only such mock-or pseudo-Portuguese.

On the other hand, despite the deep respect shown for the powerful Ottomans, the caliphs of all the Muslims and patrons of the Holy Cities, in these texts and the representation of the embassy as being, after all, a success, the reader of the Aceh works can hardly fail to distinguish some bitter notes of grudge or grievance against the Sublime Porte. As the historical overview above reveals, both features were caused by the humiliating experiences of the Acehnese both at the time of the embassy (the difficulty in receiving the sultan's audience and an excessively long wait for the response to the Acehnese plea) and in its aftermath (defeat in their attacks on Malacca, resulting from the Ottoman sultan's insufficient help). To save the face of their patron (and his successors), the Acehnese authors had to resort to various strategies of redressing the humiliation, which constituted an important point of their political agendas.

As far as $H H T$ is concerned, its author achieves the goals of his political agenda by neither concealing the anti-Portuguese nature of the embassy (represented as Malaccan, but patterned on the Acehnese), nor by redressing 
the humiliation (for in his narrative no humiliation took place). To learn how and why he managed to achieve his goals in such a unique manner, what goals exactly he pursued and through which strategies, it would be logical now to address the political agenda of HHT's author. However, to better understand those issues, some details on $H H T$, its date, nature and sources should be discussed first.

\section{HIKAYAT HANG TUAH: ITS DATE OF COMPOSITION, "PALIMPSESTIC" NATURE AND LITERARY SOURCES}

$H H T$, one of the most popular pieces of traditional Malay literature, ${ }^{5}$ is a specimen of national heroic-historical epic, in which history is unfolded through a collective half-fictitious biography of its protagonists. These are the great warrior, diplomat and merchant Laksamana (admiral) Hang Tuah and his four sworn brothers, the Sultan of Malacca, the Bendahara (grand vizier) and some other characters. These figures, whose significance is illustrated with interconnected stories of their exploits, rises and falls, trials and tribulations, embody the changeable fortunes of the Malacca sultanate. The epic begins with Malacca's early years and continues to describe its political apogee, the unexpected conquest of Malacca by the Portuguese in 1511 and its re-conquest in 1641 by the united forces of the Dutch and the Sultanate of Johor, Malacca's successor. The epic draws material from a substantial body of sources such as oral legends and traditions as well as written narratives ranging from Panji and Seri Rama tales to Hikayat Iskandar Zulkarnain and Sejarah Melayu, the mine of information from which HHT borrowed, elaborated and embellished about twenty episodes. ${ }^{6}$ Yet, as we shall see, the sources of HHT's Turkish episode are rather specific.

The majority of students of Malay literature believe that in its final form in which it is known to us HHT was composed by an anonymous author-editor in Johor in the mid-seventeenth century, not earlier than 1641 (the date of the re-capture of Malacca, which is the last event mentioned in HHT). ${ }^{7}$ This does not exclude the possibility that some of its constituent parts existed prior to that time, probably in oral form. However, for different reasons, some scholars $^{8}$ are inclined to shift the date of composition of the entire work or of its later part, which, inter alia, includes the Turkish episode, closer to the end of the seventeenth century.

Sharing this inclination, I would date $H H T$ after either 1679 or 1688 and not later than the 1710s. Elsewhere (Braginsky, 1990:399-403), I have 
tried to substantiate a hypothesis that HHT's author not only had described the developments which took place in the Malacca era, but, by means of the same narrative, had also alluded to events of the Johor era. Thus, his work is a kind of "palimpsest", in which the author's Malacca implies not only Malacca per se, but also Johor as if "shining" through it. For instance, in the earlier part of the text we can hear an echo of the war between Johor and Jambi (which ended in 1679) and probably of the rise and fall of the famous Johorese laksamana (admiral) Abd al-Jamil, who died in 1688. ${ }^{9}$ The palimpsestic nature of $H H T$ allows us not only to cautiously suggest the date of its composition, ${ }^{10}$ but also to better understand its specific character, which is important for the definition of the Turkish episode's political agenda.

The episode is incorporated into a long section of HHT which tells of the Malaccan sultan's embassies to China, Vijayanagar, Siam and Turkey, all led by Hang Tuah. These descriptions of diplomatic visits, just like Hikayat Aceh's story of the acknowledgement of Iskandar Muda's royal power and grandeur by monarchs of East and West (Iskandar, 2001:87-98), are intended to show the recognition of Malacca's (read Johor's) high standing in "global politics".

As Teuku Iskandar (1970:44) correctly remarks, the Johorese story of Hang Tuah's mission is based on Acehnese sources. One of them, indeed, is Bustan, which provided the HHT's author with information on Alauddin al-Kahar's embassy and a great number of descriptions, sometimes quoted verbatim in HHT (see below). ${ }^{11}$ However, Bustan could not have been his only source, since crucial motifs of the mission's problems in Istanbul are absent from Bustan. The second source used by the HHT's author was Lada Secupak 1 or an Aceh text similar to it. This version, which narrates the origin of the maulud (prophet's birthday) celebration in Aceh, was recorded in 1891 by C. Snouck Hurgronje (1906, I:208-10), but, as I have already noted, it may be about two centuries older. Lada Secupak 1 runs as follows:

An unnamed ruler of Aceh decides that the time has come to establish relations with the sultan of Turkey (Rum), the sovereign of all Muslims. He gives orders that an embassy consisting of his grandees be sent to Istanbul with a tribute, a shipload of black pepper (lada), to confirm his homage to the overlord. The envoys easily find lodging in Istanbul, but, as no one in the city has ever heard of Aceh, the Turkish officials refuse the envoys' request for the sultan to grant them audience. In the hope that they will somehow manage to obtain an audience later, the envoys spend a year or two in Istanbul. After their provisions have come to an end they start selling pepper to buy food. Finally, returning one Friday from the mosque, the sultan notices the envoys 
in the crowd and, surprised by their strange garments, asks his retainers who these people are. Having learnt that they are ambassadors of Aceh who were not allowed audience, the sultan loses his temper, reprimands the officials for their stupid arrogance, and invites the envoys to his palace without delay. Very happy but at the same time embarrassed, the envoys tell the sultan about Aceh and avow that originally they had brought him a shipload of pepper as Aceh's first tribute. However, because of their terrible plight they had been forced to sell most of it, so that now no more than a quart (secupak) of that pepper remained. Yet the sultan benevolently accepts their modest gift and gives them a great cannon as a return present (later it gets the name Lada Secupak). At their request, he also sends to Aceh a number of masters to teach the Acehnese various crafts unknown to them. In the end, he says that since Aceh is so far from Turkey, he releases his new vassal-state from dispatching regular embassies and tribute, the symbols of submission to a suzerain. Instead, every Acehnese village should never forget to annually celebrate the Prophet Muhammad's birthday (maulud, Aceh: molot). This will be their tribute to the sovereign of all Muslims.

It is precisely this constellation of key motifs from Lada Secupak 1 (with the exception of maulud and vassalage) that make up the plot of HHT's Turkish episode. This constellation includes the following motifs: the mission's ease of finding a place to stay; the initial difficulties in being allowed into the sultan's audience; the envoys' long wait in Istanbul; the sultan's accidental encounter with the envoys on the way from the mosque after the Friday prayer; the immediate invitation of the envoys to the palace after this meeting; their merciful reception by the sultan and his compliance with their request. Alongside these motifs, HHT's author may have also known at least one episode from Lada Secupak 2 incorporated in the Acehnese epic Hikayat Meukota Alam. ${ }^{12}$ According to the latter, the embassy took an extremely long time to reach Istanbul, since the envoys lost their way in the ocean and wandered about for two years, living on rice and the pepper that had been sent to the sultan as a present; yet, after their arrival in Istanbul, the sultan received them without delay (Sabil, 1932:4-6).

Finally, as the following sections of this paper will show, the author most probably used some oral information about Turkey to supplement his Turkish episode. The effectiveness of this channel is confirmed by Hikayat Aceh's account of how, through word of mouth, events in Istanbul became known in Aceh (Iskandar, 2001:97-98). Another example is a remark by the author of Hikayat Peperangan (...) Sultan Istambul (Tale of the war (...) of the Sultan of Istanbul) that a Turkish gentleman, Ahmad Effendi, had told him these anecdotes of the Crimean War while he was in Penang in 1877 
(the same year that the war began; Braginsky, 1996:193-94). With all this background knowledge of $H H T$ in mind, we can at last address the political agenda of its author.

\section{HIKAYAT HANG TUAH AS A FIGHTER IN THE "WAR OF BOOKS": THE AGENDA OF ITS AUTHOR}

The very fact that HHT's Turkish episode is composed on the basis of events from the history of Aceh, the major belligerent rival of Johor for more than a century, may allude to the polemical nature of the agenda of HHT's author. There were serious political reasons for these polemics.

In the early Acehnese era, until the end of Sultan Salahuddin's reign (1530-1539), Johor-Aceh relations were largely peaceful. However, after Sultan Alauddin al-Kahar deposed his brother Salahuddin, relations became openly hostile. The Acehnese repeatedly attacked and destroyed the capitals of Johor. In 1564 (under Alauddin al-Kahar) and in 1613 (under Iskandar Muda) the Acehnese even succeeded in capturing the sultans of Johor together with their families and almost the entire court, and in appointing puppetrulers in Johor and its dependencies. Johor's attempts to retaliate remained on the whole unsuccessful until the reign of Iskandar Thani (1636-1641). In 1640 Iskandar Thani made a grave political mistake when he refused to enter the coalition of the Dutch and the Johorese against Portuguese Malacca. Iskandar Thani spurned the alliance because he had been greatly affronted by the Dutch treatment of Johor as a political entity equal to Aceh; in Iskandar Thani's view Johor remained a vassal of Aceh, when in fact at the time it was an independent state. In 1641 the coalition seized Malacca, which, despite innumerable attempts, Aceh had never managed to accomplish, and the Johorese ascribed the major role in this victory to themselves.

This was "a demarcation line" in the history of Johor. Since that moment, the gradually weakening kingdom of Aceh ceased to be a threat to Johor, which in the second half of the seventeenth century re-established its relations with China and India (two of Hang Tuah's ambassadorial destinations!) and restored its suzerainty over Pahang which had been violated by Aceh. Finally, in the 1670s-1680s Johor reached the apogee of its glory, overshadowing Aceh as a commercial, political and military power (see Andaya, 1975:2327, 127-65; Sher Banu, 2010:307-13).

The author of HHT did not, of course, challenge the actual history of these events, but he did upset their reflection in the mirror of Acehnese 
texts, both read and heard. His polemic, therefore, took the form of a "war of books", so typical of traditional Malay literature (which is indeed not alone in that regard). ${ }^{13}$ The story of Hang Tuah's voyage to Istanbul in HHT includes all the motifs of Acehnese narratives brought forth by Alauddin alKahar's embassy. Like them, HHT begins with the departure of a diplomatic mission to Turkey to obtain cannons, and proceeds to the long wait for the Ottoman sultan's audience, to the audience itself and to the final success of the mission. And yet, despite the motifs being essentially the same, HHT's author skilfully transformed them to adapt to the requirements of his own political agenda.

Thus, HHT's author pursued the following goals:

(a) To appropriate the Acehnese mission to Turkey and to present Malacca (read Johor) as the first country of the Malay world to have sent an embassy to that greatest of all Muslim empires.

(b) To minimize the effect of Portuguese domination over Malacca.

(c) To represent the Hang Tuah embassy as a complete success, in which no humiliation was involved.

(d) To argue that, just as the Malaccan/Johorese embassy was superior to Aceh's on all scores, Malacca/Johor surpasses Aceh in might and greatness-this was the overarching objective of his political agenda.

The Turkish episode in HHT begins with the voyage of Hang Tuah's embassy to Aceh, at a time when Sultan Salehuddin is said to be on the throne. This can imply two things. First, that the Malaccan/Johorese ambassadorial fleet came to Aceh in an era of peaceful relations between the two states. Second, that the Malaccan/Johorese embassy to Istanbul preceded that of Alauddin al-Kahar. As the major source of this episode is Bustan, in which the reigns of both sultans are provided with dates, the author of HHT could hardly fail to have known the sequence of their reigns and his choice of the Salehuddin era (corresponding to that of Johor, not Malacca!) was most probably deliberate. This choice allowed him to present the Malaccans/ Johorese, not the Acehnese, as the first who sent envoys to Turkey.

As to the Portuguese, it does not seem far-fetched to assume that their "splendid absence" in our Acehnese texts of the second half of the seventeenth century can be explained by a virtual taboo on their mention, resulting from a chain of humiliating circumstances. This chain begins with the failure of Alauddin al-Kahar's attacks against the Portuguese caused by insufficient support from Turkey, because the fleet promised to the Acehnese embassy 
never appeared on the Acehnese roadstead, and because the Ottoman Empire lost interest in operations in the Indian Ocean too quickly. The chain continues with the disgraceful defeat of Iskandar Muda's attack of 1629, when Malacca's Portuguese garrison of some 500 soldiers destroyed 19000 of his men and all their ships (Boxer, 1964). And it concludes when, in 1641, Iskandar Thani missed the last opportunity to triumph over the Portuguese, having refused to join forces with those of the Dutch and Johorese. In such a context, it was really a better option to feign complete ignorance of the Portuguese. Moreover, precisely in the second half of the seventeenth century when HHT was written, Iskandar Thani's widow and Iskandar Muda's daughter, Sultana Taj al-Alam Safiatuddin Syah (1641-1675), and popular Acehnese storytellers made great efforts to glorify the memory of her father (Braginsky, 2006:454-55).

Johor, on the contrary, despite similar problems with the same enemy in the past (conveniently "forgotten" in HHT), had finally defeated the Portuguese by the late seventeenth century, which somehow redressed its old humiliations. More importantly, it was hardly possible for Johor to forget the Portuguese who had captured Malacca, their ancestral home. This loss was always bitterly lamented by Johor and described as a tragedy in the Malaccan/Johorese chronicle Sejarah Melayu, the main source of HHT's author. All this forced HHT's author to reject the strategy of treating the Portuguese as taboo. It is true that in HHT's Turkish episode Portugal figures only in the list of countries which Hang Tuah allegedly visited (and even this probably in the manuscript of Dewan Bahasa dan Pustaka only; Khalid, 1967: 468). However, the Turkish episode begins right after the last of Hang Tuah's many victorious battles with the Portuguese, the battle which directly threatened Malacca and in which he was badly wounded (Ibid.: 428-35). Thus, from the outset, the reader cannot fail to understand upon whom the cannons, for which Hang Tuah was sent to Istanbul, are intended to fire in defence of Malacca. Yet, having retained the Portuguese in his text, the author found a purely literary method of dealing with their humiliating presence. Normally, episodes in $H H T$ are fairly long, but the episode dealing with the Portuguese is completely different. On one page (of HHT's almost 500 pages) we learn that Puteri Gunung Ledang has established herself as the queen of Malacca. On two following pages the Portuguese, with the help of a trick, capture Malacca, from which God Almighty turned His face. On only the third page the Johorese have made an agreement with the Dutch and by the fourth page they have recaptured Malacca (Kassim, 1968:486-90). 
Thus, by drastically speeding up the rhythm of narration, the author "leaves out" 130 years of Portuguese rule in Malacca or, rather, "compresses" those years into insignificance. After the Johorese victory of 1641, he obviously considered himself entitled to do so.

Needless to say, HHT's author could not tolerate the motifs of poverty and misery from Lada Secupak 1, in which the embassy spent two years in Istanbul, hoping for the sultan's audience. He equally rejected the Lada Secupak 2 motif of the embassy's disgraceful loss of its way and consumption of almost all of the gift to the Turkish sultan during their wanderings ( Lada Secupak 2). But he did not fail to notice the potential of the motif of wandering, which he transformed in an ingenious manner. According to HHT's author, Hang Tuah's embassy never lost its way (indeed how could it, being led by the great admiral himself?). However, Hang Tuah piously decided to use the infrequent voyage to Turkey as an opportunity for performing his hajj to Mecca and Medina and, in addition, for visiting Egypt to buy cannons there, just in case. This inventive explanation constitutes only the first half of the author's interpretation of the embassy's long absence. The second half of it is even cleverer.

According to $H H T$, when the Malaccan/Johorese mission with its twenty chief grandees finally arrives in Istanbul, Hang Tuah is greeted first by the harbour-master (syahbandar) and afterwards by Ibrahim K(h)akan (Khan), one of the highest Turkish officials. Ibrahim Khan adopts Hang Tuah as his son and provides the embassy with a mansion, in which the Malays enjoy a luxurious existence. Remarkably, Ibrahim Khan is a real historical figure of the first decades of the seventeenth century (he died in 1622) and the governor of several Ottoman provinces in different years (Mordtmann, 1971: 307). HHT's description of his grandeur and opulence (Kassim, 1968:46162) corresponds quite well to this noble rank. In addition, Ibrahim Khan was a son of Sokollu Mehmet Pasha, the architect of the Ottoman's antiPortuguese policies in the Indian Ocean (Casale, 2005:58-59). Therefore, his representation in the hikayat as the main supporter of the Malaccan/Johorese cause and Hang Tuah's patron may have somehow echoed the stance of his father in the Acehnese-Turkish negotiations. Unsurprisingly, Ibrahim Khan strives to arrange for his "son" an audience with the sultan. The attitude towards Hang Tuah's request for an audience shown by "a vizier closest to the sultan" (Kassim, 1968:468), that is, the grand-vizier himself, was also depicted as rather positive. Nevertheless, even they considered this audience to be completely impossible. 
Here we face the most ingenious device of HHT's author, who states (falsely) that the strict diplomatic protocol (adat) of the Ottomans prohibits foreign ambassadors from appearing in person before the sultan. Instead, they must be content with a reception by his four viziers, who, in their turn, will deliver their monarchs' missives to the sultan (Kassim, 1968:460-61, 469). This, in fact, is the second half of the explanation for why Hang Tuah's mission took so long. The reason given is that he had to search for a way to circumvent this prohibition for almost a year. However, as soon as the sultan chances to see Hang Tuah, he is so captivated by the Malaccan/ Johorese ambassador's valour and good looks, refined manners and humility, eloquence in Turkish, and loyalty to his king (Ibid.:470, 472-73) that an incredible order to break the protocol and invite him to an audience is issued in no time (Ibid.:471).

Finally, $H H T$ describes the sultan's affection for the Malaccan/Johorese ambassador - a symbolic representative of his country and king-as becoming so great that Hang Tuah receives even more than that for which he originally asked (and which the Acehnese received neither in reality nor in their narratives). He gets not only as many cannons as he desires (according to the author, eight hundred), but also priceless gifts for his royal master, including the skullcap and turban from the head of the Ottoman sultan, the caliph of the faithful himself (Ibid.:474).

To conclude this account of the political agenda of HHT's author, Hang Tuah's imaginary embassy to Turkey is presented in HHT not only as the first in the history of the Malay world, but also as much more successful than the real Acehnese mission on every score. HHT's author did everything in his power to find felicitous solutions for everything that posed a threat to his political agenda, especially for the embassy's humiliatingly long stay abroad. His narrative is constructed in such a manner that no sign of humiliation is detectable at any stage. For what humiliation can there be in either performing the hajj, in a successful visit to Egypt, or in an unbreakable diplomatic protocol being broken only once for the Malaccan/Johorese envoy alone? From now on Malacca/Johor is recognized as a great power across the entire political space from China to Turkey. In the person of the author's hero, Hang Tuah the ambassador, Malacca/Johor is shown more respect and given more support and assistance than Aceh managed to muster through its mission. Therefore, Malacca/Johor succeeds in excelling Aceh in glory and might, at least symbolically. Thus the overarching goal of the author's political agenda is achieved. 
Why the eight hundred cannons brought by Hang Tuah and arranged around Malacca in concentric circles failed to defend the city against the fire of similar circles of Portuguese guns is a totally different story, which involves the arrogance and insanity of humans, the wrath of God and the reign of a woman. ${ }^{14}$

\section{HIKAYAT HANG TUAH'S ISTANBUL CLAD IN ACEHNESE GARB: THE CITY AND THE SULTAN}

The Turkish episode of $H H T$ is interesting not only for its author's political agenda fulfilled by means of the palimpsestic manner of his narrative and ingenious reinterpretations of Aceh sources. No less fascinating are his descriptions of Istanbul and the Ottoman sultan, for which the author chose a grand, imperial literary style also developed in Aceh (see below). Among HHT's many depictions of Istanbul, an extensive story of the city that Ibrahim Khan told to Hang Tuah over the course of two days is particularly stimulating. Here is an excerpt from his first day's narration, which is divided into three sections for the sake of convenience: ${ }^{15}$

(1) As to the city of Rum, which is called Istanbul, it is encircled by seven (concentric) tiers of walls and by seven tiers of moats. There are six great gates (in the walls) arranged (at equal distances). If you enter the sunrise (eastern) gate and walk to exit from the sunset (western) gate, this will take three months, and the distance from the earthward (southern) gate to the seaward $\left(\right.$ northern $\left.{ }^{16}\right)$ gate is the same. And if (you wish) to walk around the city, it will take twelve months. So vast it is! Each of the seven tiers of the city's walls is different from the others: one tier is constructed of black stone, another of yellow stone, yet another of green stone; there are walls built of copper, and damasked steel, and undamasked steel, and lead, and tin, while one tier of the walls is made of green emeralds (and jewels) of yellow and red colours, which shimmer and gleam, reflecting the sunlight. And each gate also differs in appearance from the others. ${ }^{17}$

(2) In the middle of the city there is a lake (lit. inner sea) as vast as a high sea: when an elephant stands on its opposite shore, you cannot see it (from your shore). And all kinds and sorts of fish have been released to inhabit this lake. Besides, a very high island always shrouded in mist rises within the lake. A great variety of plants, and flowers, and fruits grow on this island, so that, when the sultan (lit. king) wishes to enjoy himself, it is precisely there to which he sets off for entertainment. On the shore of the lake, an expansive forest has been made for him, into which a multitude of wild beasts has been released. And when His Majesty desires to go hunting, he departs for this forest. 
(3) Besides, on the eastern shore of the lake, a bustan, that is, a garden of unspeakable beauty, has been made for him, which stretches for four thousands fathoms. And various flowers and most diverse fruit-trees have been planted in that bustan, which His Majesty calls the Park of Ecstasies $(\ldots)^{18}$

(Kassim, 1968:455-56). ${ }^{19}$

A remarkable feature of this story is that each section thereof has an obvious prototype in Malay literature. Section 1 is a free paraphrase of the description of a princess's palace from Hikayat Inderaputera (Mulyadi and Braginsky, 2007:34, 46-48), while the prototypes of the two following sections are the portrayal of Bijanegara (Vijayanagar) and the garden of Acehnese sultans from, respectively, Sejarah Melayu (Chambert-Loir, 1994:56) and Bustan (Iskandar, 1970:44). ${ }^{20}$ Needless to say, one can hardly expect much realism from the description of Istanbul based on excerpts from such sources. And yet, the manner of selection and amendment of these excerpts, of their adjustment to each other and overall arrangement, seems to show that HHT's author had some idea of Istanbul's layout and major landmarks. Consequently, striving to express this idea, he used the excerpts like mosaic or jigsaw pieces which, having fallen into place, produce a picture. Moreover, the excerpts' highly conventional and generalized literary style which blurs the contours of realistic details further facilitated the expression of the author's idea, or mental picture, of the city.

All exaggerations aside, we can notice that section 1 that tells of the walls of Istanbul is well applicable to its walled western or European part. ${ }^{21}$ It is true that here and there the walls of Istanbul existed as two or three more or less parallel rows, but it is impossible to speak about several layers of its walls as a whole. However, the palaces of Istanbul did have several walls, which, even if not concentric in the proper sense of the word, enclosed courtyards placed one inside the other. The major royal Topkapi Palace situated in the western part of the city had five walls of this kind (including a corresponding section of the city-wall) and as such is represented on old maps of the sixteenth to seventeenth centuries. ${ }^{22}$ Considering that the author's source, Hikayat Inderaputera, did describe the palace, a confusion of "concentric" palace-walls with the city-walls cannot be excluded.

Section 2, which in fact is only the second half of Bijanegara's portrayal (the first half telling of its walls is replaced by the above paraphrase), depicts a lake or inland sea (tasik) inside Istanbul as vast as a high sea. It also describes an island with a garden in this lake-sea and an artificial forest on the other (?) 
shore full of wild animals where the king enjoys hunting. One can assume that the vast lake-sea is the Bosporus (probably including a segment of the Sea of Marmara) that divides Istanbul into its western and eastern (or Asian) part. If this is true and if the above-mentioned walled space is not so much the entire western part of the city as the Topkapi Palace, the hunting area on the shore can be located in the eastern part of Istanbul. There, behind the palace-garden complex of Ûsküdar and other royal parks, which "served as annexes to the Topkapi Palace", there lay hunting grounds "stocked with game" ready to be chased by sultans. For this purpose they frequently crossed the Bosporus in their red imperial barges-caique (Necipoğlu, 1997:34, 37, 38).

In the Bosporus, between the Topkapi Palace and the Ûsküdar Palace, old cartographers also placed a small island with the high Maiden's or Leander's Tower upon it, associated with a romantic legend (Necipoğlu, 1997:56, Fig. 6b). ${ }^{23}$ Although, in contrast to the Malay description, there is no garden around this insular tower, there is one nearby, around another tower on a promontory of the eastern shore, namely the spacious Lighthouse Garden (Necipoğlu, 1997:38-39, 56, Fig. 6b). Is this one more confusion of the author, which prevented him from amending his source?

Be that as it may, he did make two important amendments in section 3. Describing the garden of Ottoman sultans, he inserted the phrase "on the eastern side of the lake-sea" lacking in his Acehnese original. This directly points to the above-mentioned royal parks in the eastern part of Istanbul and confirms our assumption that in section 2 the author also implied the "other side" of the Bosporus, since both hunting grounds and major parks were located there. In addition, he increased four times (from 1000 to 4000 $\operatorname{depa}^{24}$ ) the length of the Acehnese royal garden to transform it into one worthy of the Ottomans. The author's idea of using Bustan's portrayal of the Acehnese garden for a representation of the Ûsküdar garden (or rather, gardens), its Turkish counterpart was also felicitous. Both were surrounded by walls with beautiful gates, both stretched along the water (in Aceh along the river, in Istanbul along the Bosporus), both were arranged asymmetrically and embellished with pavilions, kiosks and fountains of every sort and kind (in the Acehnese park, these were infrequently constructed by Turkish masters), both were planted with innumerable varieties of flowers, fruit trees and vegetables (Iskandar, 1966:48-52, cf. Necipoğlu, 1997:35-37).

Needless to say, in generalized portrayals emphasising their grandeur and resplendence the two gardens revealed much more similarity than they did in reality, and therefore, the Acehnese garden fitted in well with the mental picture 
of Istanbul held by HHT's author. Incidentally, contemporaneous European descriptions of Istanbul and its gardens, although made by eyewitnesses and undeniably more realistic, were not exactly photographic either. As we shall see, sometimes they shared that generalizing style to which our author (and Malay literature as a whole) so readily resorted and which helped him to make good use of excerpts from Acehnese sources.

Returning to the text of $H H T$, on the second day of his narrative to Hang Tuah, Ibrahim Khan passes from the depiction of Istanbul's overall layout, to the enumeration of the incalculable buildings and constructions of religious, social and economic purport with which this layout is filled.

And Ibrahim K(h)akan said: "O my child Laksamana, verily Rum (i.e., Istanbul) is an enormous city. The number of mosques in the city of Istanbul amounts to ten thousand eight hundred and sixty-two, and the number of pagan temples in this city amounts to one thousand two hundred and twenty. At (each) city-gate there are two wells, one before and one behind it, and the same number of almshouses for the poor. As to the total number of almshouses in the city, there are four hundred and thirteen of them. The number of Muslim markets is six hundred and fifty, while that of the markets of the infidels is three hundred and twenty-five. And six hundred and sixtyeight rivers (ending with) their estuaries flow through the city. The number of storehouses full of gold is seven hundred and sixty, while of those full of silver one thousand thirty. Besides, (in Istanbul) there are many thousands of storehouses with goods of every description, such as tin, copper and many other amazing things and fabrics: ${ }^{25}$ precious camlet, fine scarlet broadcloth and figured silk, velvet, and carpets, and kilims, and embroidered (cloths)"

(Kassim, 1968:461) ${ }^{26}$

This description which is full of figures (no matter how exaggerated) is rather uncommon for Malay literature. On the other hand, sixteenth and seventeenth century accounts of Istanbul, both European and Turkish, abound in long registers or catalogues quoting the number of all possible objects in the city (population, fortifications, buildings, guilds of traders and craftsmen, storehouses, commodities, and so on). In some cases they refer to oral sources (e.g. Lewis, 1968:102-03), in the others to written documents. Evliya Chelebi, for instance, mentions the Istanbul "catalogue" of this kind compiled for Selim II by Zekeria Efendi. He also tells of Sultan Murad IV's order of 1638 that everything in the city, especially the number and assets of its guilds, should be "re-catalogued" in minute detail, considering changes that took place since the time of Selim (Hammer, 1846, I-2:100-03). 
A small excerpt from this voluminous catalogue quoted below is not dissimilar with Ibrahim Khakan's "register" in terms of types of listed items and, though with one exception, their sequence: mosques and temples (or the Muslim and non-Muslim quarters that were normally focused on them, see Inalcik, 1978:234), almshouses, markets, conduits and waterworks, and finally storehouses. However, here the similarity ends as, in his glorification of Istanbul, Ibrahim (or rather, HHT's author) not only resorts to astronomical numbers, but also gives preference to precious things (especially describing storehouses) or things unusual for his Malay listeners. Here is the similar excerpt from Evliya Chelebi's catalogue:

Great mosques of the Sultans, 74. Great mosques of the Viziers, 1,985. Small mosques of the town-quarters, 6,990. Other mosques great and small, 6,665. Dining establishments for the poor (almshouses in HHT), 19. (...) Quarters of Moslims, 990. Quarters of Greeks, 354. Quarters of Jews, 657. Quarters of Franks, 17. Quarters of Armenians, 27. (...) Fountains public and private, 9,995. Water-pipes, 989. Establishments for distributing water, 200. (...) Wells, 60,000. Cisterns, 55. Magazines of water, 3,000. Covered markets, 3. (...) Repository for silk,1. (...) Repository for gold-wire, (...) Magazine of cloth, 1. (...) Houses for silverware, 10

(Hammer 1846, I-2: 103-04)

Remarkably a comparison of this excerpt with that of HHT helps us to clarify Ibrahim Khan's enigmatic mention of Istanbul's innumerable rivers or flows and their estuaries. This apparently is a misinterpretation of water conduits and diverse reservoirs for water listed among other things by Evliya Chelebi. In addition, Ibrahim's description of the almshouses located near the city gates may also have some realistic background. The area near the walls, which was built up relatively late, could have remained a kind of refuge for the poor for a long time. Probably precisely for this reason all the regions of Istanbul adjoining the walls (although they are not alone in this characteristic) had almshouses (see Inalcik, 1978: 230-31). Needless to say, one can hardly suspect the author of $H H T$ of reading registers similar to Evliya Chelebi's. And yet, as I have noted, information of this kind circulated orally and became accessible through conversation. Hikayat Aceh shows how, via Haramain and Yemen, discussions in Turkey reached the Malay world, while both Hikayat Aceh and HHT reveal how these discussions may have been reworked there.

The sultan's council (divan), also described in HHT, was the most important institution of the Ottoman Empire. The major functions of the divan, 
which in the second half of Suleiman the Magnificent's reign (1546-1566) actually consisted of four viziers, ${ }^{27}$ included the resolution of disputes and adjudication of grievances. Their number was usually so great that sessions of the divan frequently dragged on for a long time. Normally the sultan did not participate in the divan's meetings. However, after the meeting was finished, the viziers came before him and the grand vizier reported the major cases and discussions of the day (Lewis, 1968: 83-84; Imber, 2009: 14163). All these real features of the structure and functioning of the divan are reflected in $H H T$, even if they are shown through the actions of its members, not through explanations (Kassim, 1968: 463, 465). ${ }^{28}$ Remarkably, HHT's author, albeit indirectly, mentions the grand vizier, too, calling him "the vizier closest to the sultan". We cannot exclude that a mention of this figure, who is sympathetic to Hang Tuah but unsure whether he will succeed in arranging his audience with the sultan (Ibid.: 468-69), is yet again reminiscent of the grand vizier Sokollu Mehmet Pasha, the supporter of the Acehnese cause, represented in HHT as the Malaccan/Johorese cause.

However, the major character who determined the fate of Hang Tuah's embassy was indeed the Ottoman sultan, of whom HHT's author has much to say:

After that, His Majesty used to sit in the garden with people of his household and religious scholars of the highest rank and knowledge and to embroider skullcaps. And the sultan fed and dressed himself and his wives and children on the earnings from the skullcaps and flowers from his garden, which were sold for him daily. Such was his habit.

When a festival or a day of assembly came, His Majesty used to ascend to his palace and was seated in state there. Afterwards, he descended to a pavilion in the Park of Ecstasies. As to the pavilion, all its furnishings were made of gold, and golden alloy, and lapis lazuli, and silver inlaid with gold and jewels of exquisite craftsmanship. There were many carpets with golden patterns (in the pavilion), of which one was placed atop of it. And (the pavilion) was surmounted by a golden spire rising from the "wheel" (on the roof), which was set with gems of all sorts and small and large diamonds and embellished with strings of jewels fitting each other. And eight round goldbrocaded and silver-brocaded pillows inlaid with gems of every description and fringed with strings of matching jewels were spread out on the carpets and floor coverings (of the pavilion).

(And yet), when at night or in the daytime the sultan wished to have his royal slumber, he usually descended (from the palace) and set off to a certain tent, and in that tent he took his rest. As to the tent, its roof was made of date-palm leaves and, instead of mats, its floor was covered with gravel, and on that gravel His Majesty slumbered. Such was his invariable custom.

(Kassim, 1968: 463-64) $)^{29}$ 
There are several interesting points in this description which is so astonishing at first sight. One of them is the statement that the sultan earned his and his family's living by embroidering skullcaps and selling flowers. Incredibly, this statement is not at all as fanciful as it might first seem. First and foremost, it is intended to emphasise the sultan's imitation of the behaviour of the righteous caliphs, befitting him as the present-day caliph of the Muslims. For instance, the caliph Umar earned his "permitted" (halal) income by the craft of stonecutting. As we read in Bustan, "in the daytime Umar cut stones and sold them, thus providing for his family" (Jelani, 2008:23).$^{30}$ The same imitation is confirmed by the description of the sultan sleeping on gravel in the tent roofed by date-palm leaves. This strange tent roof and its other details originate from a combination of two other Bustan stories about the caliph Umar (Ibid: 25-26, 31), narrating that he slept on gravel under a date palm, on the branches of which his blanket was thrown-is not this a tent of sorts?

On the other hand, it is known that Ottoman princes were usually taught useful handicrafts. Mehmet II skilfully produced arrows and gave them to his friends as a sign of his benevolence (Mayes, 1956:181), while "Suleiman (the Magnificent) (...) laboured daily at a trade, so that even the prince should earn his bread by the sweat of his brow" (Lybyer, 1913:76). ${ }^{31}$ There is nothing unrealistic in sultans trading in flowers either. In the $1550 \mathrm{~s}$, a member of the Austrian embassy in Istanbul wrote that Selim II had "many pleasure gardens planted with herbs, flowers and fruits (...) Their produce provided substantial revenue for the royal purse" (Necipoğlu, 1997: 32-33). Around the same time, another European eyewitness remarked: "If we only had the revenue the Grand Turk receives from gardens we would be extra rich" (Ibid.:34).

Finally, beginning precisely with this episode about the sultan in his garden, the author of HHT starts to use in earnest the "Acehnese literary style" mentioned above.

\section{THE GOLD-AND-JEWEL STYLE OF THE TURKISH EPISODE: ACEH'S INFLUENCE ONCE MORE, AND FOR THE LAST TIME}

Proceeding from one of its salient features, the literary style dominating HHT's Turkish episode can be defined as a "gold-and-jewel" manner of representation. This manner is typical of Acehnese royal letters, thus presenting a verbal double of their style of illumination, which A. Gallop 
(2011) aptly characterized by the formula: "gold, silver and lapis lazuli". In full literary bloom, this manner of writing appears on pages and pages of texts composed in Aceh as Hikayat Inderaputera, ${ }^{32}$ Bustan, and especially Adat Aceh and Hikayat Aceh. ${ }^{33}$

In pieces of literature written in this manner, we find innumerable descriptions of palaces and treasure-houses, kings' audiences, royal processions heading for the mosque and princely weddings, diverse court ceremonies and pageants of all kinds, especially military parades. Each of these descriptions, in turn, consists of minute lists of tapestries and carpets embellishing throne pavilions, garments and ornaments of kings and grandees, wedding palanquins and royal umbrellas, flags and regalia, weapons of warriors and harnesses and caparisons of horses and elephants. All these are embellished with or made of gold, golden alloy (suasa) and silver, which are inlaid with pearls and diamonds, rubies and emeralds, lapis lazuli and "gems of nine kinds". So rich are these descriptions in precious metals and jewels and so brightly they "shine", thanks to various synonyms of the word "shining" used in them, that the solid outlines of these glittering and iridescent objects begin to dissolve. In the end, it is as if the multitude of individual glitters and glimmers separates from its material substratum to merge in a single sheer radiance, "hanging in the air", as an impressive symbol of the royal glory.

Although elsewhere (Braginsky, 2011: 56-61) I wrote of the significance of the "gold-and-jewel" manner for Malay Sufi allegories, its major purpose was undoubtedly a representation and extolling of precisely this kind of royal glory. Little wonder, therefore, that HHT's author considered this imperial Acehnese style to be most appropriate for his portrayal of the Ottoman sultan and his actions.

There are two especially graphic specimens of the author's use of this style. In the first of them, the depiction of the sultan sitting in state appears to be another paraphrase from Hikayat Inderaputera. In that text a princess sits on a throne with a revolving seat (in HHT, the sultan's throne is called the Wheel of the World) surrounded by an octagonal screen of multicoloured glass. The colour of the figures and garments of both the sultan and the princess changes as the light of different colours illuminates them:

A similarity between these descriptions is further enhanced by the fact that the continuation of HHT's description, like Hikayat Inderaputera, calls the royal throne peterana (not singasana) and mentions columns surrounding the throne, which are made from glass of different colours (Kassim, 1968:472). 


\section{Hikayat Hang Tuah}

Servants embellished the throne installed in the audience hall, and put up curtains and a canopy shot with gold and fringed with exquisite matching diamonds of every description from all corners of the world. (...) And His Majesty went out to (the audience hall) and like always was seated on his throne (called singasana) before his people, hidden by netlike curtains of golden brocade set with jewels of a thousand shapes and colours. And His Majesty's body shimmered and glimmered reflecting rays of the iridescent jewels. When he moved, (his body) became now yellow, now white, now red, now green, following the (changing) colours of jewels attached to the gold-brocaded curtains which illuminated him. And many pillows of gold and silver brocade, which lay to the left and to the right and behind His Majesty who was seated on the throne (also) flashed hundreds of (different) colours (Kassim, 1968: 464, 472). ${ }^{34}$

\section{Hikayat Inderaputera}

And the throne (peterana) of pure gold surrounded by an octagonal screen of glass was installed on that barge (...). (And they built a dais) of three levels for all those who would wait on the princess (...). The first layer was of gold, and the second layer of silver, and the third layer (was covered) with a netlike curtain (...). And (...) the princess went out of the palace, accompanied by wives of princes (...), and she was seated on the throne (...). After the princess turned to (the side of the screen made of) red glass, her appearance and garments became totally red. When she turned to the white glass, all her body became white. When the princess turned to the blue glass she became of blue colour. When she turned to the yellow glass $(\ldots)$, her body became totally yellow. When she turned $(\ldots)$ to the purple glass, her garments became totally purple (Ali bin Ahmad, 1968: 277, $280,282) \cdot{ }^{35}$

The second specimen of the "gold-and-jewel" style, which portrays the sultan's progress to the mosque, is a quotation from Bustan only slightly altered to fit the new context. Despite the author's obviously good intentions, there is some irony in the fact that in Bustan this passage narrates the transportation of the king's funeral monument to the cemetery (below, the lines that correspond to Bustan verbatim are italicized).

Meanwhile, servants covered the mosque with fabrics of diverse colours and manners of making, unspeakably beautiful in their aspect. And the royal carriage, which His Majesty used to set off for the mosque, was already prepared and waited for him, exquisitely embellished. And all the war chiefs drew up in rows. Young nobles went out of the palace, carrying swords and spears of state and royal insignia, and royal scions of mixed blood took these emblems of power from the young nobles. Then heralds, and celibate warriors of the holy war, and regalia-bearers, and youths and adolescents of various kinds took, in their turn, the emblems of power from them. Small and large cannons fired fourteen volleys, and the supreme judge King of Justice with sheikhs, and great religious scholars, and all the worshippers went out of the palace to walk at the head of the pageant. Drummers began deafeningly beating ceremonial drums. Musicians started playing gongs, clarinets, kettledrums, clarions, pipes, tambours, rattles, flutes and trumpets so loudly that they sounded like continuous rolls of thunder. When the entire pageant had proceeded outside, the royal orchestra of nine instruments began to play. And His Majesty also went forth to the mosque (followed by umbrellabearers), who opened fringed royal umbrellas of various shapes and colours. 


\section{MALAY LITERATURE}

In front of the pageant there were paraded eighty rogue elephants covered with gold-shot caparisons set with gems of all kinds. Eighty strong warriors rode those elephants, each of them with weapons on his back and golden buttons all round his chest. Standing on gilded seats, javelins in their hands, they forced the elephants to run as fast as they could, shouting and leaping (on their seats). (These were followed by) eighty war horses. Eighty strong warriors in iron chain-mails and helmets of Khurasan steel were mounted on those horses. Standing on saddles (?) inlaid with gems of all kinds, they held matchlock guns (in their hands). And while urging their horses, they deafeningly fired their matchlocks. (...) And twenty pages came to the Square of Fantasies ${ }^{36}$ to distribute alms: gold and silver and innumerable jewels. And people cheered struggling with each other to obtain those alms before the sultan.

$(\text { Kassim, 1968:469-70) })^{37}$

And, once again, roughly synchronous European accounts of real Ottoman sultans and their real armies on the march are not dissimilar to their Acehnese counterparts as used by HHT's author, which witnesses to the verisimilitude of his substitution, the reasons for which have already been explained. This, for instance, is how the ambassador of the Emperor Charles V described his impressions of the times of Suleiman the Magnificent:

The Sultan was seated on a very low ottoman (...) covered with a quantity of costly rugs and cushions of exquisite workmanship (...) The Sultan's hall was crowded with people (...), there were all the troopers of the Imperial guard (...) and a large force of Janissaries. (...) Take your stand by my side, and look at the sea of turbaned heads, each wrapped in twisted folds of the whitest silk; look at those marvellously handsome dresses of every kind and every colour (...) glittering with gold, with silver, with purple, with silk, and with velvet; words cannot convey an adequate idea of that strange and wondrous sight (...). From this (palace window) I had the pleasure of seeing the magnificent column which was marching out. The cavalry of the Imperial guard consists of these regiments (...) The spectacle presented by a Turkish horseman is indeed magnificent. His (steed has) trappings and saddle sparkling with gold and jewels in silver settings. The rider himself is resplendent in a dress of cloth of gold or silver, or else of silk or velvet.

(Lybyer, 1913:136-38)

Probably Muslim empires at both ends of the world did have a lot in common in the eyes of their admirers and in the imaginations of the masters of the generalized "gold-and-jewel" style, of which the fruits are presented in the folios of their manuscripts. 


\section{CONCLUSION}

To sum up. The anonymous author of HHT masterly fulfilled both his political and literary agenda. Using the palimpsestic manner of narration so characteristic for traditional Malay "wars of books" and alluding to Johor when speaking of Malacca, he cleverly manipulated Acehness stories of the embassy to the Ottoman court to achieve his overarching goal. As an outcome, he argued that Malacca (read Johor), not Aceh, was the first state of Malay world, which established diplomatic relations with the Ottomans and received a fantastic number of cannons necessary for the war against the Portuguese. The Malaccan (Johorese) embassy was, according to him, by far more successful than the Acehness one and, in contrast to the latter, suffered no humiliation at any stage of its sojourn in Istanbul. This was certainly a great political victory over Johor's old rival. Even if achived only on paper, it was in agreement with the leading role of Johor in the Malay world of the time when $H H T$ was composed.

As to the literary agenda of HHT's author, he fulfilled it by finding an appropriate literary manner to describe the grandeur of Istanbul and its Sultan, the caliph of all Muslims, who showed so much love, respect and benevolence to Hang Tuah (and Malacca/Johor in his person). For this purpose-somewhat ironically-he chose grand, imperial, "gold-and-jewel" style, which was also develop in Aceh. It is precisely passages in this style referring to Aceh that HHT's author skillfully combined to create his portrayals of Istanbul unprecedented in verisimilitude and detail in traditional Malay literature.

Thus, he co-opted not only battle cannons received by the Acehness from the Ottomans, but also literary canons of Acehness men-of-letters.

\section{ACKNOWLEDMENT}

I am sincerely grateful to Bilqis Hijjas for her expertly editing of my imperfect English and suggesting the title of this paper.

\section{NOTES}

1. Bustan al-Salatin dates from between 1638 and 1641; Hikayat Aceh, in my opinion (Braginsky, 2006), is traceable to the reign of Sultana Taj al-Alam Safiatuddin Syah (1641-1675); the first version of the legend of Lada Secupak (henceforth Lada Secupak 1), being one of Hikayat Hang Tuah's sources, may have been composed around the mid-seventeenth century, if not earlier, while the second version of this legend 


\section{MALAY LITERATURE}

(henceforth Lada Secupak 2) is part of Hikayat Meukuta Alam/Malem Dagang, which Drewes (1979:7) refers to the second half of the seventeenth century. On the date of Hikayat Hang Tuah, see below.

2. This summary is based on historical researches by Casale (2005) and Göksoy (2011: 68-80).

3. Although Casale's reference to Lombard (1967:37, n. 3), which allegedly confirms this, is not quite accurate, some other facts corroborate his assumption. For instance, in 1565 the Jesuits of Malacca reported the Ottoman sultan's warning that he would "refuse to receive the ambassador of Aceh unless Aceh started punishing the Portuguese" (Tiele 1880:425). In the same year, this information was confirmed in Alauddin al-Kahar's letter to Malacca saying that he "had been reprimanded by the Ottomans for his kind treatment of the Portuguese in the past" (Casale, 2005:53). Subsequently, eighteen Portuguese were summarily executed in Aceh at the insistence of the Turkish ambassador (i.e. Lutfi; Ibid.: 51-52). The Ottoman sultan's (or Lutfi's?) threat to refuse to grant the Acehnese envoy a reception was taken so seriously as it may well have been a reminder of the similar refusal to grant an audience to the previous ambassador in 1562 .

4. I use the word "palimpsest" metaphorically; the word literally means a manuscript on which the original writing has been erased to make room for later writing, but of which traces remain.

5. Studies of $H H T$ are numerous. For the earlier works including important researches by A. Teeuw, see Sutrisno (1983:21-33) and the bibliography therein. A list of representative works of the 1970s-1990s can be found in Braginsky (2004:489, note 81), to which recent publications by Harun Mat Piah et al. (2002:232-46), Maier (2004:35-108), and Koster (2007:207-62) should be added.

6. For HHT episodes borrowed from Sejarah Melayu, see Iskandar (1995:302-05).

7. Typical in this respect is a "minimal hypothesis" by Chambert-Loir (1994:44) '(...) in Johor in the mid-seventeenth century (perhaps before 1641, but somewhat retouched later) (...)'.

8. These are, for instance, Parnickel (1962) which places the dates between 1641 and 1673; Kassim (1968:xii) which attributes a part to after 1641; Sutrisno (1983: 67) which dates it to after 1676; and Iskandar (1995:299) which places it at the end of the seventeenth century at the latest.

9. Critical comments on this hypothesis by Chambert-Loir (1994:42-43 and note 6), which undoubtedly deserve consideration that may cause a correction and further substantiation of the hypothesis, can hardly discredit it as a whole, particularly with regard to the palimpsestic nature of certain parts of $H H T$.

10. Remarkably, all the datable historical figures and events of the Turkish episode, as well as the dates of its sources (dates of the Acehnese Sultan Salahuddin and Ibrahim Khakan (Khan), the Acehnese embassy to Turkey, Acehnese sources describing it, in particular Bustan, and the capture of Malacca by the Dutch and Johorese that closely follows the Turkish episode) originate from the mid-sixteenth to the seventeenth centuries, i.e. the epoch of Johor, not Malacca. The only exception is the figure of Ahmad, a son of Zain al-'Abidin, who, according to HHT became the sharif of Mecca in $886 \mathrm{H}$ (1482 AD) "on the orders of the sultan of Rum" (Kassim, 1968:444). However, in 1482 the sharif of Mecca could only be appointed by the Mamluk sultan of Egypt, not the sultan of Rum (Turkey). Even more importantly, the first Ahmad that can be found on the list of 
sharifs occupied this position in 1628-1629. There are no Ibn Zain al-'Abidins on the list at all, the closest approximation is Ahmad ibn Zaid, the sharif in 1684-1688 (see http://www.historyfiles.co.uk/KingListsMiddEast/Arabic Hashemites.htm Retrieved 3 August 2012).

11. E.-U. Kratz (1974) shows that Bustan, especially its description of Iskandar Thani's reign, was known in Johor in the mid-eighteenth century. However, as HHT reveals, it was known there about a century earlier.

12. This version is a kind of prologue to this epic (for and about which, see Sabil, 1932; Cowan, 1937; Imran, 1988). This prologue, which occurs only in a few manuscripts of the epic, is intended to emphasise the piety of its protagonist, Sultan Iskandar Muda, and his wise foreign policy, which is conducive to the strengthening of Aceh. As to the main part of the epic, it narrates the war between heroic Aceh and demonic Johor and is only loosely connected with the prologue.

13. For an interesting phenomenon of the Malay literary "war of books", see Braginsky 2004:124-26, 411-13.

14. For a stimulating interpretation of this story, see Koster (2007:246-56). My reading of this story (Braginsky, 2004:475-76), which Koster considers to be different, is, rather, complementary to his.

15. All translations from Malay are mine. The rendering of excerpts from $H H T$ follows the Kassim Ahmad edition with minor amendments in text, and consequently, translation, based on a comparison with the edition of Balai Pustaka.

16. If the seaward direction means northward (Wilkinson, 1932, II: 28), the opposite, earthward (lit. headstream) direction means southward.

17. Cf. Hikayat Inderaputera, translation: 'The palace was encircled by seven (concentric) tiers of the trellised-fence (...). (The first tier) of the palace's fence was made of damasked steel, and the gate in it was overlaid with patterned gold of most beautiful work. (...) The second tier of the trellised-fence was made of copper, while its gate of pure (lit. twenty-four carat) gold (revealed) exquisite craftsmanship. (...) The third tier of the trellised-fence was made of tin. (...) The fourth tier of the trellised-fence was made of silver, while its gate of pure gold was embellished with carvings and fretworks. (...) The fifth tier of the trellised-fence was made of an alloy of copper and gold, while its gate was of pure gold. The sixth tier of the trellised-fence was made of silver in a framework of gold, while its gate of pure gold was inset with lapis lazuli. (...) The seventh tier of the trellised-fence was made of red gold, while its gate of pure gold was inlaid with green emeralds'.

The original Malay text: Maka maligai itu tujuh lapis pagar jala-jalanya (...) Maka (...) (pertama lapis) pagar jala-jala maligai (...) perbuatannya daripada besi khursani dan pintunya ditatah dengan emas diukir, terlalu indah perbuatannya. (...) Maka (...) kedua lapis pagar jala-jala daripada tembaga, syahdan pintunya daripada emas sepuluh mutu terlalu indah-indah perbuatannya. (...). Maka (...) pagar jala-jala yang ketiga lapis daripada timah yang putih. (...) Maka pagar jala-jala yang keempat lapis daripada perak dan pintunya daripada emas sepuluh mutu, beberapa ukir dan keluk. (...) Maka (...) kelima lapis pagar jala-jala daripada tembaga suasa dan pintunya daripada emas sepuluh mutu. (...) Maka (...) keenam lapis pagar jala-jala daripada perak bersendi-sendikan emas dan pintunya daripada emas sepuluh mutu ditatah lazuardi. (...) Maka (...) pagar jala-jala yang ketujuh lapis daripada emas yang merah 


\section{MALAY LITERATURE}

dan pintunya daripada emas sepuluh mutu bertatah zamrut yang hijau (Mulyadi and Braginsky, 2007:34, 46-48).

18. Only the first lines of this long description that occupies five pages (pp. 456-60) in Kassim Ahmad's edition of HHT are quoted here.

19. The original Malay text: (1) Adapun negeri Rum yang bernama Setambul, itu kotanya tujoh lapis dan paritnya pun demikian juga dan pintu gerbangnya yang besar enam butir (beratur). Adapun apabila masok pintu sebelah matahari hidup, berjalan terbit (keluar) kapada sabelah pintu sebelah matahari mati, tiga bulan lamanya, dan sebelah pintu di hulu berjalan ka pintu sebelah laut itu pun demikian juga jauhnya. Maka apabila berkeliling negeri itu dua belas bulan perjalanan. Demikianlah luasnya. Bermula kota negeri itu selapis datang kapada tujoh lapis itu berbagai-bagai perbuatan dan jenisnya: ada yang selapis daripada batu hitam, ada yang selapis daripada batu kuning, ada selapis daripada batu hijau dan selapis pula daripada tembaga besi khursani dan besi melela dan timah puteh dan timah hitam dan selapis pula daripada zamrud yang hijau dan kuning dan merah, gemerlapan rupanya memanchar-mancar kena chahaya matahari. Dan pintu gerbangnya demikian juga, berbagai-bagai perbuatan-nya. (2) Maka (pada) sama tengah negeri itu, ada sebuah tasik terlalu luas, saperti laut rupanya; jikalau gajah berdiri (di) seberang(nya) itu pun tiada kelihatan. Sekalian jenis ikan ada dilepaskannya ke dalam tasik itu. Maka di tengah tasik itu ada sebuah pulau terlalu tinggi, sentiasa berasap rupanya. Maka di atas pulau itu ditanamkan pelbagai rupa tanam-tanaman dan bunga-bungaan dan segala buah-buahan. Maka apabila raja hendak bersuka-sukaan, di sanalah baginda pergi bermain-main. Maka di tepi tasik itu di(per)buatnya suatu hutan terlalu besar, maka dilepaskannya segala binatang yang liar-liar ke dalam hutan itu. Apabila raja hendak berburu, ke sanalah baginda pergi (bermain-main). (3) Kemudian dari itu diperbuatnya suatu bustan, erti-nya kebun, terlalu indah-indah, kira-kira empat ribu depa luasnya di sebelah matahari hidup tasik itu. Maka ditanam-nya pelbagai bunga-bungaan dan aneka-aneka buah-buahan. Maka di gelar baginda bustan itu Taman Ghairat (...) (Kassim 1968: 455-56).

20. These descriptions can be found in Winstedt (1938: 50); Simatupang and Teeuw (1958); Iskandar (1966:48-52); Jelani (2004:356-61). Incidentally, the same portrayal of Bijanegara also occurs in the Malaccan chapter of Bustan.

21. The number of portrayals of Istanbul in the Ottoman era is legion. For the city's general layout represented below I used works by Lewis (1968:127-28); Inalcik (1978:227-35); Necipoğlu (1997:32-43) and for additional details the information of the sixteenth and seventeenth-century authors Ramberti (Lybyer, 1913: 239-44, 253-56); Hierosolimitano (Austin, 2001); Evliya Chelebi (Hammer, 1834, 1846); Grimston, Gainsford and Sandys (Temple, 1907:183-98).

22. See, for instance, the maps of Munster (1550), Braun and Hogenberg (1572), Camocio (1572), Pinargenti (1573), De Beauvau (1615) in http://historic-cities.huji.ac.il/turkey/ istanbul /istanbul.html Retrieved 3 May 2012.

23. For this island and the tower, see also Austin $(2001: 27,104)$.

24. Depa, "the span of the outstretched arms", one fathom which is equal to 6 feet or 1.8 metre (Wilkinson, 1932, I:273).

25. The list of fabrics is taken from Hikajat Hang Toeah (1948:268). Kassim Ahmad's text adds to these fabrics unidentifiable jim, asteranji and sanjini (instead of suji).

26. The original Malay text: Maka kata Ibrahim Kakan: 'Hai anakku Laksamana, adapun negeri Rum ini negeri besar. Bermula masjid dalam negeri yang bernama Setambul itu 
selaksa delapan ratus enam puloh dua butir banyaknya dan rumah berhala seribu dua ratus dua puloh dalam negeri itu. Telaga di pintu gerbang itu dua butir, di dalam di luar; dan balai derma pun demikian juga, tempat orang yang kekurangan pada balai itulah. Ada pun banyak balai derma dalam negeri itu empat ratus tiga belas buah, dan pesara Islam tengah tujoh ratus dan pesara kafir tiga ratus tengah tiga puloh, dan sungainya dalam negeri itu banyaknya enam ratus kurang dua tujoh puloh butir kuala sungai itu, dan gedong berisi emas tujoh ratus enam puloh buah dan gedong berisi perak sa-ribu tiga puloh buah banyak-nya. Kemudian dari itu beberapa ribu gedong yang berisi berbagai-bagai jenis, saperti timah dan tembaga dan kain dan harta yang gharib-gharib saperti suf, sakhlat dan dewangga, beledu dan permadani dan kambeli dan suji (Kassim, 1968:461).

27. It was precisely in this period, from 1562 to 1566 , that the episode with the Aceh embassy to Istanbul took place, and although in 1566 Selim II increased the number of viziers from four to five, the former number was apparently preserved in the memory of the Malays; in the course of time the number of viziers was further increased: in 1570 to seven and in 1642 to eleven (Imber, 2009:145-46).

28. This episode is represented more clearly in HHT's edition of Balai Pustaka (Hikajat Hang Toeah, 1948:270-71, 273).

29. The original Malay text: Kemudian dari itu melainkan baginda dudok dalam taman (dengan) segala ahlu'l-bait dan segala ulama yang besar-besar mertabat dan pengetahuan-nya serta baginda menjahit kopiah. Ada pun raja itu, makan pakainya dengan segala anak isterinya, harga kopiah dan harga bunga yang di dalam taman itulah setiasa dibelanjakannya. Demikianlah adatnya raja itu. Apabila hari raya atau hari yang majlis, naiklah baginda dudok ke atas maligai; sudah itu turun ka dalam taman ghairat pada balai. (Adapun balai itu) sekalian pegawainya daripada emas dan suasa dan lazuardi dan perak bertatahkan emas permata terlalu indah-indah perbuatannya, beberapa dari permadani yang keemasan dan suatu permadani terhampar di-atas balai itu, berjentera dan berkemunchak daripada emas bertatahkan ratna mutu ma'nikam dan pudi dan intan berumbai-rumbaikan permata dikarang dan delapan butir bantal seraga daripada emas dan suasa dan perak bertatahkan ratna mutu ma'nikam dan berumbai-rumbai permata dikarang terletak di atas permadani dan kamardani. Maka apabila hari malam atau siang raja hendak beradu, maka turunlah baginda pergi pada suatu khemah; disanalah baginda istirahat. Ada pun khemah itu atapnya daripada daun khurma dan tikar-nya tempat baginda beradu itu daripada batu kelikir. Demikian-lah isti'adat baginda itu sentiasanya (Kassim Ahmad, 1968:463-64).

30. A detailed story of Umar's work as a stonecutter we find in Taj al-salatin (Roorda van Eysinga, 1827:56-57); the same book also tells of the ideal king-prophets Nabi Daud and Nabi Sulaiman, of whom the former earned his living by making chain-mails, and the latter by weaving baskets (Ibid.: 53-54).

31. I owe these two facts to my late friend and colleague, Boris Parnickel.

32. For Aceh as a probable place of Hikayat Inderaputera's composition, see Braginsky (2007:lxiv-lxv).

33. For examples of this literary manner, see, respectively, Mulyadi and Braginsky (2007: 65-68, 94-95, 131-34, 149-54, 156-57,159-61, 240-41); Jelani (2004:343-49, 371-74); Harun and Ghani (1985:45-55); Iskandar (2001:35-48).

34. The original Malay text: Maka takhta perhiasan balairung itu pun dikenakan oranglah, dibubuh tirai dan lagit(-langit) yang berpakankan emas dan berumbai-rumbaikan intan 


\section{MALAY LITERATURE}

dikarang berbagai-bagai, indah-indah rupanya, sehabis-habis dunialah. (...). Maka baginda pun berangkat-lah keluar dudok semayam pada tempat sediakala dihadap oleh sakalian itu dalam kelambu jala-jala emas yang bertatahkan permata yang beribu-ribu bagai rupa-nya dan warna-nya. Maka tuboh baginda itu pun gilang-gemilanglah lantas keluar di-hadap oleh chahaya permata itu. Apabila baginda bergerak, sa-ketika warna kuning, sa-ketika warna puteh dan merah dan hijau, ikut saperti warna permata yang terkena pada kelambu jala-jala emas itu. Dan beberapa butir bantal seraga daripada emas dan perak dan tembaga suasa yang berkilap-kilap beratus jenis terletak pada kiri kanan dan belakang baginda semayam itu (Kassim Ahmad, 1968:464, 472).

35. The original Malay text: Maka di atas pelang itu diperbuatnya suatu peterana daripada emas sepuluh mutu dan dindingnya delapan persegi itu diperbuatnya daripada kaca (...) (Maka diperbuatnya) tiga pangkat tempat segala orang mengadap tuan puteri itu (...). (Pertama pangkat) daripada emas, dan kedua pangkat daripada perak dan ketiga pangkat tembaga suasa dan suatu di-perbuat-nya daripada jala-jala (...). Maka (...) tuan puteri keluar dari istana diiringkan oleh segala bini raja-raja (...). Maka tuan puteri pun duduklah di atas petarakna (...). Syahdan apabila tuan puteri itu berpaling pada kaca merah itu maka rupa pakaian tuan puteri pun menjadi serba merah dan jika tuan puteri berpaling kepada kaca putih maka warna tuboh puteri itu pun putihlah. Maka jikalau tuan puteri (...) berpaling kepada kaca biru itu maka warnanya tuan puteri itu pun jadilah biru dan jika tuan puteri berpaling kepada kaca kuning (...) maka warna tuboh tuan puteri itu pun menjadi serba kuning. Maka jika tuan puteri itu berpaling (...) kepada kaca ungu maka warna pakaian tuan puteri menjadi serba ungu (Ali bin Ahmad, 1968:277, 280, 282).

36. Or the Square of Riders, see Lombard (1967:133, note 1).

37. The original Malay text (the lines corresponding to Bustan verbatim are italicized): Maka masjid itu pun disaputlah orang dengan kain berbagai-bagai warnanya dan perbuatannya terlalu indah-indah rupa-nya. Maka raja keretan emas kenaikan baginda berangkat ke masjid itu pun hadhirlah musta'id dengan perhiasannya terlalu indahindah. Maka segala hulubalang pun berdirilah bersaf-saf. Maka silah kerajaan dan segala alat kerajaan pun turunlah di-bawa segala lela-lela di-sambut oleh segala megat-megat. Maka bentara dan segala bujang sabilu'llah dan segala kundangan meremong dan muda belia sakaliannya pun datanglah menyambut segala alat kerajaan. Maka bedil meriam pun dipasang oranglah dua kali tujoh. Maka Kadhi Maliku'l-Adil dan segala syaikh ulama yang besar-besar dengan segala ahlu'l-ibadah sakaliannya pun turunlah berjalan dahulu. Maka gendang arak-arakan pun dipalu oranglah terlalu azmat daripada gong dan serunai, negara, nafiri, bangsi, merangu, cherachap, medali, demama, terlalu gemuroh bunyi-nya (seperti tagar) tiada berputusan. Maka segala pawai pun turunlah dan gendang nobat pun berbunyilah. Maka baginda pun berangkat-lah. Maka payong iram-iram pun terkembanglah berbagai-bagai (rupa) warnanya. (Maka) pertama-tama (yang) berjalan itu delapan puloh gajah tunggal, semua-nya pakaian gajah itu keemasan bertatahkan ratna mutu manikam, dan di atas gajah itu delapan puloh pahlawan yang memikul alat peperangan dan berkanching emas selitar dadanya dan memegang lembing buang-buangan berdiri di-atas kursi keemasan. Maka gajah itu pun digerakkan pantas-pantas serta ia tempik melambong-lambong dirinya. Dan delapan puloh kuda perang; maka di atas kuda itu delapan puloh pahlawan berbaju zirah dan berketopong besi khursani terdiri di atas kursi yang bertatahkan ratna mutu manikam memegang bedil istinggar. Apabila kuda itu diburunya, maka bedil itu pun 
dipasangnya terlalu gempita bunyinya. (...) Maka biduanda dua puloh orang itu pun datanglah berdiri di medan khayali itu mengamborkan derma sedekah daripada emas dan perak dan permata yang tiada terkira-kira banyaknya lagi. Maka terlalulah ramai segala khalayak (BP itu,) sakalian berebut mengambil sedekah di bawah hadrat raja itu (Kassim, 1968:469-70).

\section{REFERENCES}

Ali bin Ahmad (ed.), 1968. Hikayat Inderaputera. Siri Pengetahuan Bahasa dan Sastera Dewan Bahasa dan Pustaka 18. Kuala Lumpur: Dewan Bahasa dan Pustaka. Andaya, L., 1978. The Kingdom of Johor 1641-1728. Kuala Lumpur: Oxford University Press.

Austin, M. (introd., transl.), 2001. Domenico ’s Istanbul. Ed. by G. Lewis. Wiltshire: Gibb Memorial Trust.

Boxer, C.R., 1964, "The Achinese Attack on Malacca in 1629, as Described in Contemporary Portuguese Sources”. J. Bastin dan R. Roolvink (eds.), Malayan and Indonesian Studies. Essays Presented to Sir Richard Winstedt on his 85th Birthday. Oxford: Clarendon Press, pp. 105-121.

Braginsky, V., "Hikayat Hang Tuah, Malay Epic and Muslim Mirror; Some Considerations on its Date, Meaning and Structure" in Bijdragen tot de Taal-, Land- en Volkenkunde 146-4: 399-412, 1990.

Braginsky, V., "Russians, Circassians and ... the Discovery of Laser Weapons: The Story of the War between Sultan Istanbul and the Russian Czar Alexander" in Indonesia Circle 70: 193-217, 1996.

Braginsky, V., 2004. The Heritage of Traditional Malay Literature; An Historical Survey of Genres, Writings and Literary Views. Leiden: KITLV Press.

Braginsky, V., "Structure, Date and Sources of Hikayat Aceh Revisited: The Problem of Mughal-Malay Literary Ties" in Bijdragen tot de Taal-, Land-en Volkenkunde 162-4: 441-67, 2006.

Braginsky, V., 2007. "Pengenalan II. Hikayat Inderaputera: Dongeng Indah dan Perbendaharaan Rahsia”. S.W.R., Mulyadi \& V.I. Braginsky (eds.), 2007.

Hikayat Inderaputera. Ketua Editor Hassan Ahmad. Kuala Lumpur: Yayasan Karyawan. (Projek Karya Agung.)

Braginsky, V., "Light, Sound and Fragrance: the Impact of Sufism on the Aesthetics of Traditional Malay Literature" in Malay literature 24:1, pp. 51-69, 2011.

Casale, G., 2005, “'His Majesty's Servant Lutfi': The Career of a Previously Unknown Sixteenth-Century Ottoman Envoy to Sumatra Based on an Account of His Travels from the Topkapi Palace Archives" in Turcica 37:43-81, 2005. 
MALAY LITERATURE

Chambert-Loir, H., "L'Espace Politique dans la Hikayat Hang Tuah". R. Ptak (ed.). South China and Maritime Asia Vol. 1, pp. 41-61, 1994. Wiesbaden: Otto Harrassowitz.

Cowan, H.K.J., 1937. De Hikajat Malem Dagang; Atjehsh Heldendicht, Text en Toelichting. Leiden: Koninklijk Instituut voor Taal-, Land- en Volkenkunde.

Drewes, G.W.J. (ed., transl.), 1979. Hikayat Potjut Muhamat: An Acehnese Epic. The Hague: Martinus Nijhoff. (KITLV. Bibliotheca Indonesica 19.)

Gallop, A.T., 2011. "Gold, Silver and Lapis Lazuli; Royal Letters from Aceh in the Seventeenth Century". R.M. Feener, P. Daly and A. Reid (eds.). Mapping the Acehnese Past. Leiden: KITLV Press. (KITLV. Verhandelingen 268.)

Hammer, R.J. von (transl., introd.), 1834. Narrative of Travels in Europe, Asia and Africa in the Seventeenth Century by Evliya Efendi, vol. I. (pt. 1). London: Parbury, Allen and Co.

Hammer, R.J. von (transl., introd.), 1846. Narrative of Travels in Europe, Asia and Africa in the Seventeenth Century by Evliya Efendi. Vol. I, pt. 2. London: Parbury, Allen and Co.

Harun, R. \& T.R. Ghani, 1985. Adat Aceh. Jakarta: Proyek Penerbitan Buku Sastra Indonesia dan Daerah.

Harun Mat Piah, Ismail Hamid, Siti Hawa Salleh, Abu Hassan Sham, Abdul Rahman

Kaeh \& Jamilah Haji Ahmad, 2002. Traditional Malay Literature. Kuala Lumpur: Dewan Bahasa dan Pustaka.

Hikajat Hang Toeah, 1948. Djil. II. Djakarta: Balai Poestaka

Imber, C., 2009. The Ottoman Empire, 1300-1650; The Structure of Power. 2nd edition. New York: Palgrave Macmillan.

Imran, Teuku Abdullah, 1988. Hikayat Meukuta Alam: Suntingan, Teks dan Terjemahan Beserta Telaah Struktur dan Resepsi. Jakarta: Intermasa. (ILDEP Series.)

Inalcik, H., 1978, "Istanbul”. The encyclopaedia of Islam. New edition. Vol. IV. Leiden: Brill, pp. 224-48.

Iskandar 1966. Bustanu’s Salatin. Bab II. Fasal 13. Kuala Lumpur: Dewan Bahasa dan Pustaka.

Iskandar, Teuku, "Some Historical Sources Used by the Author of Hikayat Hang Tuah" in Journal of the Malaysian Branch of the Royal Asiatic Society 38:2, pp. 15-47, 1970.

Iskandar, Teuku, 1995. Kesusasteraan Klasik Melayu Sepanjang Abad. Brunei: Jabatan Kesusasteraan Melayu, Universiti Brunei Darussalam.

Iskandar, Teuku (ed.), 2001. Hikayat Aceh. Ketua Editor Hassan Ahmad. Kuala Lumpur: Yayasan Karyawan. (Projek Karya Agung.)

Jelani Harun (ed.), 2004. Bustan al-Salatin (Bab Pertama dan Kedua) Karangan 
Nuruddin ar-Raniri (Siri Warisan Sastera Klasik). Kuala Lumpur: Dewan Bahasa dan Pustaka.

Jelani Harun, 2008. Bustan al-Salatin Bab Ketiga; Kisah Raja-Raja Yang Adil. Kuala Lumpur: Dewan Bahasa dan Pustaka.

Kassim Ahmad (ed.), 1968. Hikayat Hang Tuah. Kuala Lumpur: Dewan Bahasa dan Pustaka.

Koster, G.L., 2007, "Enemies or Relatives: Images of the Portuguese in Hikayat Hang Tuah". V. Braginsky and B. Murtagh (eds.). The Portrayal of Foreigners in Indonesian and Malay Literatures: Essays of the Ethnic 'Other'. Lewiston, Queenston, Lampeter: The Edwin Mellen Press, p. 207-62.

Kratz, E.-U., 1974. "Bustan-Copy and the Johor Histories. Paper". The Sixth International Conference on Asian History, International Association of Historians of Asia (I.A.H.A). Yogyakarta, 26-30 August.

Lewis, B., 1968. Istanbul and the Civilization of the Ottoman Empire. Norman: University of Oklahoma Press.

Lombard, D., 1967. Le Sultanat d'Atjeh au Temps d'Iskandar Muda 1607-1636.

Paris: L'École Française d'Extrême Orient.

Lybyer, A.H., 1913. The Government of the Ottoman Empire in the Time of Suleiman the Magnificient. Cambridge: Harvard University Press. (Harvard Historical Studies 18).

Maier, H., 2004. We are Playing Relatives; A Survey of Malay Writing. Leiden: KITLV Press. (KITLV. Verhandelingen 215.)

Mayes, S., 1956. An Organ for the Sultan. London: Putnam.

Mordtmann, J.H., 1971. "Ibrahim Khan" in The encyclopaedia of Islam. New edition, vol. III. Leiden: Brill, London: Luzac, p. 307.

Mulyadi, S.W.R. \& V.I. Braginsky (eds.), 2007. Hikayat Inderaputera. Ketua Editor Hassan Ahmad. Kuala Lumpur: Yayasan Karyawan. (Projek Karya Agung.)

Necipoğlu, G., 1997, "The Suburban Landscape of Sixteenth-Century Istanbul as a Mirror of Classical Ottoman Garden Culture" in A. Petruccioli (ed.), Gardens in the

Time of the Great Muslim Empires; Theory and Design. Leiden: Brill, pp. 32-71. Parnickel, B.B., 1962, "Johorskaya Redaktsiya 'Povesti o Hang Tuahe”" (The Johor Recension of the "Tale of Hang Tuah") in Narody Azii i Afriki (Peoples of Asia and Africa) 1: 147-55.

Roorda van Eysinga (ed.), P.P., 1827. Tadj oes-Salatin; De Kroon Aller Koningen. Batavia: Lands Drukkerij.

Sabil, T. Mohamad (transl.), 1932. Hikajat Soeltan Atjeh Marhum (Soeltan Iskandar Moeda). Batavia: Balai Poestaka.

Sher Banu A.L. Khan, "Ties that Unbind; the Abortive Aceh-VOC Alliance for the 
MALAY LITERATURE

Conquest of Malacca 1640-1641" in Indonesia and the Malay World 38-111, July: 303-21, 2010.

Situmorang, T.D., \& A. Teeuw (eds), 1958. Sedjarah Melaju Menurut Terbitan Abdullah. Djakarta: Djambatan.

Snouck Hurgronje, C. 1906. The Achehnese. Translated by A.W.S. O'Sullivan, vol. I-II. Leiden: Brill.

Sutrisno, Sulastin, 1983. Hikayat Hang Tuah: Analisa Struktur dan Fungsi. Yogyakarta: Gadjah Mada University Press.

Temple, R.C. (ed.), 1907. The Travels of Peter Mundy in Europe and Asia vol. I. Travels in Europe 1608-1628. Cambridge: The University Press. (The Hakluyt Society, Second series 17.)

Tiele, P.A., "De Europeërs in den Maleischen Archipel" in Bijdragen tot de Taal-, Land- en Volkenkunde 28:1, pp. 408-82, 1880.

Wilkinson, R.J., 1932. A Malay-English Dictionary (Romanised), vol. I-II. Mytilene: Salavopoulos and Kinderlis.

Winstedt, R.O., 1938, "The Malay Annals or Sejarah Melayu" in Journal of the Malayan Branch of the Royal Asiatic Society 16:3, pp. 1-225. 